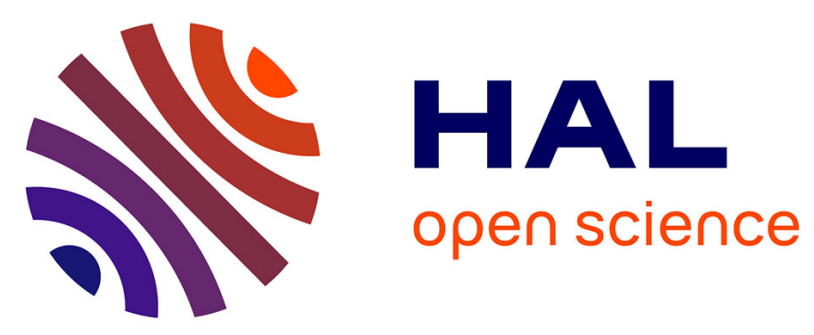

\title{
The globalization of gender
}

Ksenija Vidmar-Horvat

\section{To cite this version:}

Ksenija Vidmar-Horvat. The globalization of gender. European Journal of Cultural Studies, 2005, 8 (2), pp.239-255. 10.1177/1367549405051846 . hal-00571473

\section{HAL Id: hal-00571473 \\ https://hal.science/hal-00571473}

Submitted on 1 Mar 2011

HAL is a multi-disciplinary open access archive for the deposit and dissemination of scientific research documents, whether they are published or not. The documents may come from teaching and research institutions in France or abroad, or from public or private research centers.
L'archive ouverte pluridisciplinaire HAL, est destinée au dépôt et à la diffusion de documents scientifiques de niveau recherche, publiés ou non, émanant des établissements d'enseignement et de recherche français ou étrangers, des laboratoires publics ou privés. 


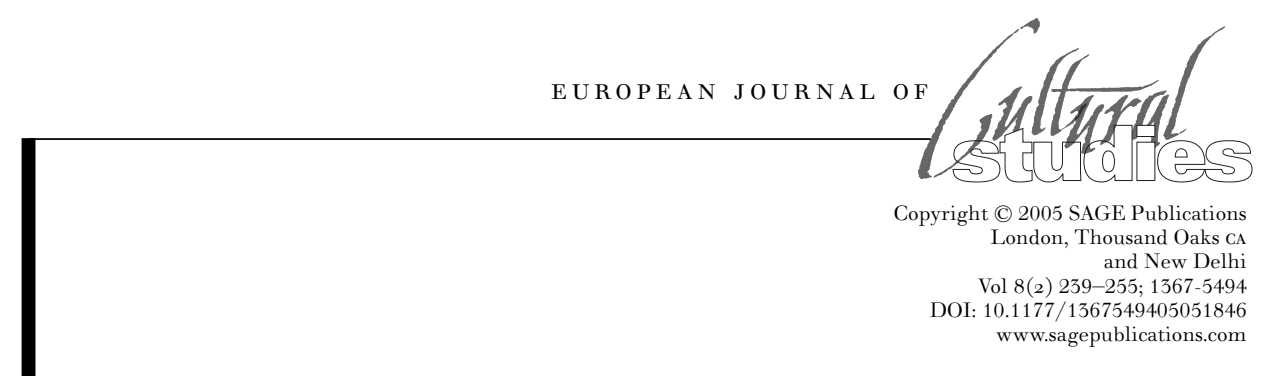

\title{
The globalization of gender
}

Ally McBeal in post-socialist Slovenia

Ksenija Vidmar-Horvat

University of Ljubljana

\begin{abstract}
This article looks at the American TV series Ally McBeal and the meaning of the lead character for young college audiences in postsocialist Slovenia. Critical examinations of the series have pointed to the problematic construction of the character's gender identity based on the notion of liberated femininity. This notion has been seen as especially problematic with reference to feminist politics. When discussing the character and its social portrait with sociology undergraduate students in Slovenia, however, the series' construction of the post-feminist character attracts a different set of meanings. Rather than engaging in the debate with western feminism, the analysis suggests, Ally's popularity in Slovenia may be

understood from the way in which the character and the series allow local audiences, and women's audiences in particular, to come to terms with their own social biographies in the period of transition.
\end{abstract}

KEYWORDS gender, globalization, global television, post-feminism, postsocialism, Slovenia, transition society, women's audiences

This article examines the American TV series Ally McBeal and its reception in post-socialist Slovenia. During the past few years, the series has generated substantial interest among critics. Much of the interest has been rooted in the programme's innovative approach to TV drama and its unique representational techniques, which even led some to compare David Kelly's commercial product to David Lynch's Twin Peaks and Dennis Potter's The Singing Detective, a masterpiece of television work (Nochimson, 2000: 26-7). Simultaneously, the positioning of the young, attractive and professionally successful lawyer as the lead character has inspired critical inspection of the series' representations of the contemporary 'new woman'. Because the series' target audience has been defined as the '18-34 female market', one key concern regards how the programme's politics of representation relates to and articulates the social experiences of this generation of women. Because the generation has been described also as having 'grown up taking for granted the feminist 
victories won by their mothers and thus for whom feminism exists at the level of popular common sense rather than at the level of theoretical abstraction' (Moseley and Read, 2002: 238), inadvertently, the construction of women's 'post-feminist' identity triggers questions regarding the programme's relation to the feminist agenda (Dow, 2002; Dubrofsky, 2002; Kim, 2001; Moseley and Read, 2002). In this article, this second line of enquiry will be chosen as a starting point for an examination of Ally $\mathrm{McBeal}$ as a post-feminist female television character. Also, it will look at possible shifts in the meaning of post-feminism when the series' audiences are young college women in post-socialist Slovenia.

As a post-feminist character, no doubt Ally offers a fruitful terrain for inspecting television's relationship with feminism and, more broadly, the popular politics of remembering feminism. However, the global success of the series also puts into question the ideologically exclusive equation between the series' politics of representation and the implied western female spectator (Cooper, 2001) involved in a cultural war over the feminist past. A different, non-western-oriented analysis might indeed give rise to a different set of meanings than the prevailing literature suggests. In view of recent ethnographic media scholarship, it can be argued that the success of the programme cannot be explained properly without considering local social and political histories of gender, which define structures of identification for the audiences and help to create their worlds of pleasure (Ang, 1996). As will be argued within the limited scope of this article, the global popularity of the series and its post-feminist character can be illustrated by the fact that it provides a global cultural site which allows local audiences, and women's audiences in particular, to imagine and re-imagine their own social biographies. As these biographies in many ways depart from western feminist politics and history, they both deploy and contest the meaning of post-feminism in its current, commercial televisual discursive form.

My own interest in the meaning of global media idols such as Ally McBeal arose from the classroom experience. In the 2000/2001 sociology of culture class, we spent some time discussing the cultural impact of global media products and female icons in particular. By then, I had become an avid viewer of Ally McBeal and formed my own 'way of seeing', which was based primarily on questioning the ideological effect of the lead character and her alleged 'progressiveness' in terms of gender and sexual politics. However, the debate with the students in which I presented Ally as a case revealed that they had developed different views of the programme. Intrigued by the difference, I asked them to spend some more time on the issue by answering a short questionnaire: 49 first- and secondyear undergraduate sociology students (40 female and nine male) responded. The responses obtained cast an interesting light on the dynamic interplay of cultural products and local audiences as they form the imagined, global media community. Both pedagogically and analytically, 
watching Ally McBeal in post-socialist Slovenia calls for reconsideration of the construction of meaning of global ideals of femininity and their involvement in local social histories of gender and sexual conflicts.

\section{The comic female and historical constructions of femininity}

Critics emphasize that as a televisual character, Ally McBeal addresses an emergent market niche of professional, middle- and upper-middle-class (white) women,

who actually like working, who have discovered a job can be both absorbing and worthwhile, who feel their own salary is something to be treasured and who, although defining themselves through their jobs, are not excluding men from their lives. (Slaughter, quoted in Gough-Yates, 2003: 89)

Consequently, they see her arrival as a positive turn in the politics of representation of women in commercial media: 'One can't expect total satisfaction, yet issues may get presented, and more sympathetically, than elsewhere - for example, in mainstream cinema' (Rapping, quoted in Margolis, 2000). Joan Gershen Marek observes along similar lines that since "women now account for about one half of the new lawyers in the United States', the mere fact that Ally is represented as a professional woman who is not 'defined by [her] relationship to a man', suggests a novel approach to portraying professional women, which can be 'a positive thing for both sexes' (Marek, 1999).

As a commercial medium, television relies on rationalization of its success by taking into account its target audiences (Ang, 1991). Consequently, TV programmes cannot ignore audiences and their lifeworld experiences. Yet, to assume a simple reflective mode of the series, mirroring the worlds of a social group or generation of women, as this body of work does, risks missing the complex work of television as a fictional medium. As Ella Taylor (1989: 3) writes, 'Television comments upon and orders, rather than reflects, experience, highlighting public concerns and cultural shifts'. By the same token, it can be argued that the contemporary, post-feminist 'new woman' has addressed the 'fortunate minority of women' as much as it has constructed the 'symbolic of femininity' (Gough-Yates, 2003: 38); that is, it has provided a visualnarrative field of selection, exclusion and repression of other, alternative forms of femininity. In other words, female characters on television play a role in both representing and constructing the norms and ideals of contemporary femininity. The latter is not arrived at arbitrarily but in relation to the governing power maps of sexual and gender relations.

The double process of reflection-construction of femininity was at work prior to Ally McBeal's arrival. Ally's predecessors, a 'long line of 
strong heroines' (as the promotional booklet to the three-volume video series calls them), attest to television's simultaneous ability to speak to real women while channelling their desires towards socially accepted gendered positions. Two of them, Lucy Ricardo of I Love Lucy and Mary Richards of The Mary Tyler Moore Show, which have been considered by the industry to be crucial to the character's genealogy, are the most popular and paradigmatic cases to observe. Based on her ambition to become a star, Lucy's plots could be seen as reflections of postwar women's audiences condemned to 'domestic containment'. 'Weekly, for six years, [Lucy] accepted domesticity, only to try to escape again the next week' (Mellencamp, 1986: 88). However, as Patricia Mellencamp (1986: 90) writes, granting a woman the place of the performative winner could not secure her escape from the "confinement and the tolerance of kindly father $[\mathrm{s}]$ '. Finding herself in the new work environment, the comic female of the 1970s represented the single woman as a 'content individual who did not need a heterosexual partner to define her identity' (Lotz, 2001: 107); but she had to trade her newly-gained independence for being positioned back in the patriarchal scenario of domestic entrapment - this time in the symbolic form of the family at work.

In contrast to Mary Richards, who was 'situated as both daughter and mother in the show's 'family' of co-workers' (Lotz, 2001: 107), in Ally McBeal a woman's substitution of family for career is replaced by searching for a symbiosis between career and personal life. Personal and professional lives become integrated and inseparable:

She can be an excellent lawyer in court - not quite as outrageous as her boss Cage, infinitely superior to her boss Fish - but her legal arguments almost invariably serve as a lens on her private life or on romance, her personal cause even when the romance in question doesn't concern her. (Appelo, 1999: 11)

Most importantly, as she progresses in the male world, Ally does not try to imitate the masculine mode of practising law but insists on feminine qualities, combining sensitivity with sexuality, care with availability. 'Ally is a living fictional proof that, in our day, a female character can wear a miniskirt and still play on the boys' field' (Appelo, 1999: 4). In the series, femininity becomes an identity to be valued, not repressed.

It is the series' rehabilitation of femininity which presents an upfront difficulty for most of the feminist critique. Ally $M c B e a l$ openly celebrates femininity but proposes it in a sexual rather than political form. L.S. Kim (2001) has argued that post-feminist sexual liberation has been an act of masquerade based on self-objectification. Self-objectification, she writes, 'does not necessarily achieve subjectivity, and it can be a false freedom' (2001: 324). Kim's view can be supported further by looking at Ally's sexuality, which is expressed in the regressive form of a growing female adolescent rather than that of a mature woman. Her bodily transfor242 mations - from the shrunken pose in the chair to the inflated breasts or 
lips - visually revisit the time of adolescence which, as we know from the character's family biography (concerning especially her parents' divorce), is operative in Ally's inability to form a lasting intimate relationship (Margolis, 2000). In contrast, in Lucy's time, the body of the adolescent fairytale character was transfigured to comment on postwar women's flight from domesticity (Vidmar, 1995). The 1950s cultural representation of the adolescent girl articulated women's resistance to social confinements of domesticity and motherhood, whereas the 1990s comic female resists abandoning adolescence. She remains a young girl in the symbolic, corporate world of the tolerant fathers.

Last but not least, the restoration of femininity unfolds within a maledominated cultural field. For example, Moseley and Read find evidence of the series' rehabilitation of femininity in representation of Ally's subjectivity by allowing the viewer access to her emotions. It is interesting that they refer to what Lydia Curti has called 'famous window scenery'. The visual expression of her inner thoughts and feelings is given to us 'as she stands at her office window, looking out over the city - a position to which the series returns her repeatedly' (Moseley and Read, 2002: 243). The window is a classic Hollywood reference, a culturally specific generic code, which stands as a 'fundamental icon of melodrama, with its obvious reference to prison, closure, victimization' (Curti, 1992: 147). It prefigures the woman's social place as a spectator 'outside the "real" arena of social relations and power, with all the connotations of passivity, waiting, and watching normally attached to the function of spectatorship' (Doane, 1987: 78; emphasis in original). While 1990s television rehabilitates the comic woman's inner, intimate worlds by making them visible, it also subjects them to the masculine visual codes of power and control.

Taken together, all three sites of construction of femininity are a justifiable object of critique. Above all, they put into question the narrative of progress in the politics of representation of women in mass media in the past few decades.

\section{Post-feminist reinvention of feminism}

From the perspective of the scholars who have examined the programme's construction of post-feminist femininity, the series becomes most problematic at the point where it constructs a narrative of femininity in the (feminist) past. Moseley and Read find an explanation for the programme's appeal in the fact that it attempts to reconcile 'feminist desires' with 'feminine desires' (Moseley and Read, 2002: 238). The reconciliation suggests, however, that the two were essentially exclusive in the past and that it is only within post-feminist discourse that the act of merging can be complete. The proposition legitimates the post-feminist politics of identity. In so doing, it also fabricates a certain memory of feminism. 
The process of fabrication is evident in the construction of Ally's 'glorified single status'. In his review of the urban comedy genre, Michael Tueth has described its universe as having been 'about the risk and the discomfort of alternatives. It is not a rush toward a monolithic, mainstream ideal, but a tumbling convergence of various channels of information and values' (Tueth, 2000: 107). Ally's character resonates this new, postmodern politics of identity by occupying simultaneously different, often exclusive subject positions:

Women should be married. Society drills it into us. Smart people should have careers. Society drills it into us that women should have children and mothers should stay at home. And society condemns the working mother that doesn't stay at home. What chance do you really have when society keeps drilling us? We can change it, Renée. Society is made up of more women than men and if women really wanted to change society, they could do.

I plan to change it. I just want to get married first. (Ally McBeal, 'Silver Bells')

Marketed as 'McBealisms', the statements such as the ones above form the multivocal and polysemantic universe which, as aforementioned, has attracted so much critical acclaim for the show. Moreover, Ally entertains the idea of the lack of closure on identity, understanding - not unlike women's readers of popular romances (Radway, 1986) - that the pleasure of fulfilment is in anticipating, not reaching the end. As Ally reveals at the end of the first episode:

The real truth is that I probably don't wanna be too happy or content, because then what? .. I I actually like the quest, the search. That's the fun - the more lost you are, the more you have to look forward to ... What do you know? I'm having a great time and I don't even know it. (Ally McBeal, 'Pilot')

As the series progresses, however, the open-ended structure of a woman's fantasy turns out to be a claustrophobic scenario. Singlehood does not liberate Ally, but makes her a prisoner of past choices, formulated in the post-feminist fashion as the question, as Kim has put it, 'What's a girl to do?' (Kim, 2001: 319).

'So, here I am - the victim of my own choices,' Ally states in the opening episode. The choice to which she is referring concerns the decision to study law at Harvard after she had just broken up with her sweetheart Billy, who enrolled at Princeton. Although the opening scene of the first episode reveals that Ally has passed the exam which Billy has not, and therefore posits women as intellectually superior, it is nonetheless played out against a backdrop of a woman's drama or, better still, of the drama of womanhood in patriarchy: of the irreconcilable marriage between romance and career in a woman's life. Throughout the series, the 24.4 comic side of the character soothes this conflict. It also inscribes an ironic 
distance which, in contrast to Lucy's gesture of self-ridicule, is oriented toward the extra-diegetic space of the feminist spectator.

Ally's choice implies a feminist gesture, although with a new meaning. Rachel Dubrofsky has argued that, as a television character, Ally performs a reactionary, post-feminist gesture of aestheticization of the political; that is, in Rayna Rapp's words, 'the reduction of feminist social goals to individual "lifestyles" (quoted in Dubrofsky, 2002: 278; emphasis in original). Moreover, Dubrofsky laments:

$[\mathrm{N}]$ ot only is the show not political, it actually encourages political stasis and reinforces and reinscribes the present political structures - the very same ones that cause Ally so many problems ... by diverting our attention away from these back to the personal. (2002: 279)

The 'lifestyle feminism' is evident when, for example, Ally states: 'The definition of the nuclear family is constantly evolving. The time is coming. It has to start somewhere. And it would have to start with me' - making feminist politics looking like a commodity that can be purchased and abandoned at will.

As a post-feminist comic character, Ally never reflects upon the feminist history which has secured her social privileges as a white, middle-class, educated woman, but she does engage in dialogue with feminism when her personal happiness is at stake. As Dow (2002: 263) writes, an implied assumption of the series' discourse is that 'it is feminism that has landed women like Ally in their predicament - educated and professionally successful, yet loveless and childless'. Dow goes on to argue that 'feminism has never promised women happiness - only justice' (2002: 263). Yet the rehistorization of feminist politics is crucial to the process of consolidation of post-feminist ideology. By merging women's social gains with the personal agenda of (sexual) liberation, post-feminist memory obliterates the interconnectedness and codependency of both, yet paradoxically falls into its own trap when blaming feminist restructuring of the sexual relations and politics of gender for not finding personal fulfilment.

The series' post-feminist politics of representation present a problem of interpretation. As Moseley and Read have suggested, it can be seen as a successful dramatization of the coming together of 'traditional feminist values with a historically and materially different experience of being young and female' (Moseley and Read, 2002: 240) in the age of postfeminism. It can also be observed as it reconstructs the popular memory of feminism as a means to force hegemonic interpretive lenses on women's audiences and their social experiences. In either case, this body of critical work suggests that an important part of the meaning of the series resides in the troubling relationship between femininity, feminism and postfeminism. 


\section{Post-feminism and transitional fantasies}

The problematic treatment of feminism by the series and its sexual and gender politics is a legitimate cause of concern for the critical western viewer who has lived through both phases: second-wave feminism and its aftermath. In the global context this culturally specific, albeit subtle televisual battle over the legacy of feminism, acquires a different meaning. In post-socialist transition societies, which have all witnessed women's resistance to western feminism, certainly this can be argued to be the case. Jacqueline Andall (2003: 6) explains the rejection of feminist politics on the grounds of the 'difficulties that Eastern Europeans have experienced in articulating their difference to Western feminism'. The resistance may also have to do with a memory, this time of the socialist, rather than the feminist, past.

The image of Ally McBeal was first used in my sociology of culture class to introduce a debate about the relationship between media images of independent and autonomous women, women's actual social experiences and global consumerism. It was only after I had heard consenting voices towards Ally's picture, suggesting that she presents a positive novelty compared to the politics and practices of representation in Slovene past and present media, that I became intrigued. In the questionnaire which followed this classroom experience, I therefore decided to ask the students openly about the social portrait of Ally McBeal; whom they thought she represented; how her image compared to cultural representations of women in Slovenia; and, under the title 'Ally and Feminism', what in their opinion were the local social effects of global female icons like her.

The students described Ally in such contradictory terms as 'romantic, confused, with a wild imagination', 'confused, searching for her man, which she cannot find because of her over-idealized expectations'. Further, she was seen as 'weird, hysterical, sometimes pathetic, sometimes likeable', but also as 'self-confident, daring, feminized but human, vulnerable, caught up in fantasies (like all of us)'. Some emphasized the character's strength of being professionally 'successful, self-confident and independent', while others pointed out her emotional instabilities and weaknesses and, interestingly in one response, overdependency on men and their paying attention to her. It was this latter aspect that in one student's mind made Ally an improper role model to be adopted by Slovene audiences. A female student supported the first one's view that she could be a role model, 'considering her economic independence and professional success, but harder when taking into account her emotional intelligence'. As another contradicted, it was a nice change for the lead role to be 'given to a woman who is financially independent and, although anorexic, beautiful and smart'.

Notwithstanding conflicting views of the meaning of the character's emotional (in)stability, Ally was described almost unanimously as the 
embodiment of the new social group (or class) of career women. Although some were suspicious of Ally as a caricature, there seemed to be a shared consensus that she represented the social advancement of women in the West (especially the United States) and imprinted a progressive chapter in the social history of women's emancipation in general. 'The series tries to show a typical representation of the western generation of women', a student wrote. Another agreed: '[Ally] is representative of a growing number of emancipated women who in the West are becoming more and more independent.' Interestingly, however, it was only in one response that a student observed a paradox, that this new western figure 'still nurtures idealized visions of the traditional woman, especially in relation to the family'.

When asked about the social effects of the 'new woman' in Slovenia, multiple investments in the character were laid out. 'This is one of the few series (foreign, there are no Slovene ones) that show the emancipation of women', a female student wrote. Another saw in Ally's figure an incentive for women to 'dare to do more for themselves'. Two other girls wrote that Ally carried the promise of having 'a positive effect on stereotypes about women who are supposed to be housewives and take care of the family. Women would at least contemplate their fate', and that Ally would 'help to improve the social position of women in Slovenia'. These responses clearly articulate a belief in the liberating effect of the character, even when the series' politics of representation was perceived in an antagonistic sense as a threat:

[Ally] increasingly corresponds to the figure of a career woman who does not care or have time for her family; more important to her are professional success, career ... Slovene women have resented these influences so far, but the growing emancipation of women is putting pressure on the value of a career.

In this student's view, Ally-like characters 'would create growing tensions between the sexes, which could cause the crisis of the family as the basic social unit'.

A recurring theme was the character's challenge to the 'traditional', 'conservative' and 'stereotypical' cultural depictions of womanhood. The traditional clearly signified the local culture, while the progressive was identified with the West. 'Traditional is not the only proper way' as far as representing women is concerned, a student responded to the question of whether they would like to see more characters like Ally on Slovene television: 'Media representations are different here, linked more to traditional understanding of women's roles.' The same female student also pointed out that she believed that in Slovenia, the role of mother is valued over a career. Another pointed to stereotypical depictions of women as housewives and taking care of the family. The implied understanding was 
that the series destabilized this politics of representation with progressive messages. The students were aware of media practices of idealization, which they associated with the economic logic of American commercial television and/or American culture in general ("Americans have a tendency to complicate and overreact'). Yet because 'Slovenia is still traditional in terms of representing women in the public sphere', programmes such as Ally McBeal were seen as having positive impacts on Slovene television production as well as on popular consciousness in a broader sense. Characters such as Ally would eventually evolve on Slovene television, a 'logical consequence of Americanization'; 'Slovenia is moving with the times (dictated by the US) and it is right to present the different, more equal and independent position of women in society'.

The 'traditional' in the equation signalled the transitional encounters with the socialist past. 'Slovenia has not grown out of socialism entirely', a student commented. The vision of repressed femininity that has spilled over from the socialist past came up a number of times (students spoke of a sense of stiffness, the rigidity and pessimism of the culture), one which I have encountered in the classroom ever since. This is puzzling, especially when taking into consideration the specific political and historical context of Slovene society and its socialist past. Slovenia (and Yugoslavia) invented its own version of socialism, marked by periods of economic and political liberalism and greater openness to the West (Ramet, 1999). As the most western of the former Yugoslav states, Slovenia in particular was involved in the daily exchange of labour and commodities with neighbouring Italy and Austria. Moreover, after Tito's break with Stalin's Informbureau in 1948, the country became less rigid in its distancing from anything remotely western. On the contrary, 'American culture was a strong force in setting the norms of various aspects of everyday life, including things such as bodily beauty, desirable objects (cars, houses, clothes, furniture), or romantic affairs' (Crnkovic, 2003: 159). My own research on the Slovene leading women's magazine of the postwar period reveals a similar, early trend to introduce consumerism and lifestyle cultures to female audiences, while replacing the working mother imagery with modern and independent urban ideals of femininity (Vidmar, 2002; Vidmar and Antic, forthcoming). Hence, for women living in socialist Slovenia, insertion of individuality and femininity has not been an entirely novel experience.

As viewers, we have different unconscious stakes in either identifying with or refuting characters such as Ally; this goes for ascribing historical meanings to them also. Growing up within socialism, which invented its own version of gender equality through the 'woman's question', one would expect at least some evidence of its residual form to compete for ideological space with the global media's depictions of the post-feminist mode of women's liberation. However, in her study of TV re-runs, Lynn Spigel observed a tendency to construe a sharp discontinuity between the present and the past concerning women's progress, when in her class she asked 
students to compare sitcom female stars, such as Lucy from the 1950s television show. She also observed that this tendency was enforced by their distillation of simplified notions of the women in the past from the reruns. This should not be read merely as a sign of illiteracy in the field of critical media and television studies, Spigel points out, for professional readings are as selective as popular ones. However, they can be seen as a way of negotiating the place in the present to make it 'more tolerable' (Spigel, 1995: 21). As Steven Knapp (1989: 142) writes, 'the focus of authority is always in the present; we use, for promoting and reinforcing ethical and political dispositions, only those elements of the past that correspond to our sense of what presently compels us'.

According to Spigel, this historical, cartoonish depiction of women can be seen as a way of celebrating the audiences' own 'enlightenment in the present' (Spigel, 1995: 20). In transitional Slovene culture, the notion of repressed, socialist femininity has been used in different ideological service to negotiate women's gendered positions in post-socialist times. This is certainly evident in the conservative project to 'redomesticate' women, seen in the former eastern bloc countries as well as in former Yugoslav states. The appeals for the repatriarchalization of society and acceleration of right-wing androgyny have been borne on the depiction of socialism as an anomaly, a 'totalitarian vestige' which forced women to occupy unnatural roles outside the family and domesticity (Jogan, 2000: 22). This politically mastered view has ruled over public discourse and mass media during the past decade and has acquired in the process a 'commonsense' quality. Identifying with Ally in this sense may be seen as a defence strategy to confront the post-socialist ideology of women's proper social place in the family. However, two other elements can be highlighted that may relate to Ally's popularity with the students. Both have to do with the 'production of expectations' (Jogan, 2000) in respect to gender and power relations in transition societies.

In the case of Slovenia, when in 1991 the country began its 'transition' to market economy and democracy, a promise that women would increase their political visibility and economic independence was articulated. Soon, the promise proved problematic. The mid-1990s witnessed an actual decline in women's political participation (the number of women in parliament dropped from 12 in 1992 to seven in 1996, climbing back to 12 in 2000) while the politics of sexual segregation in formal and informal work, as well as the income gap, have continued to sustain gender inequality in the economic and social life of the country's post-socialist state. The editor of a popular women's magazine commented on the missed opportunity: 'Because, as it appears, women should not be pushed to the front, the problems, which concern a good half of the population, will continue to be handled by the male minority' (Lupša, 2001: 3). Moreover, as already mentioned, the conservative forces embarked on misogynistic discourses, disguised as moral calls for redomestication and repatriarching 
of women. Paradoxically, as Slovene sociologists have noted, processes of democratization were operative within this because they were borne on assumptions about the self-propelling of social and political rights, fought by and for women in socialism. Without giving any serious thought to perseverance of sexual and gender inequality in private life from the socialist past, as one Slovene sociologist put it, transition did not accelerate the erosion of androgyny; it temporarily blocked it (Jalušić, 1999; Jogan, 2000).

It appears that this development has had a gender-specific impact on the younger generation as well. According to recent research, titled 'The Social Vulnerability of the Young' (Ule et al., 2000), young adolescent girls have lost out the most in the transition period in Slovenia. Although gender difference in education in Slovenia is declining, and in certain cases women actually excel in terms of formal education (in 1998, out of 8612 graduates, 5043 or 58.5 percent were female graduates), the research shows statistically that young girls increasingly show a lower degree of self-respect and self-worth. Contrary to previous studies showing the assertiveness of young girls, a recent tendency seems to be their withdrawal into inner worlds. The study concludes that instead of solving problems, young girls are facing them with insecurity and anxieties. As the authors summarise, young women have been the hidden losers of the transition society (Rener, 2000).

'It is almost impossible to expect more characters like Ally on Slovene television,' a student wrote, 'because despite democracy, the woman is still subordinate, even though she is a lawyer or a politician.' With regard to readers of women's magazines, Joke Hermes (1995: 51) has argued that 'fantasies of ideal selves that may or may not correspond to real life, or to one another ... give readers the feeling [that] they will be able to cope'. By the same token, images of autonomous and professionally successful women on television can be seen to provide terrain for audiences to cope with their own expectations. 'Ally encourages women to begin to think that they deserve to be equal to men.' She proves to us that 'we are not alone in this', she makes women realize 'that they should stand up for themselves'. A female student highlighted Ally's status as an educated woman: 'Ally is an educated, emancipated woman, who sees the world in her own way.' Education for women can be seen as one of the more important social achievements of Yugoslav socialism. Yet, as the abovementioned study reveals, the promise to accelerate social advantage via education has been stalled for women by the transition. Encountering the post-feminist character as a representative of the educated and emancipated woman therefore provides an outlet for the hope and belief in what Giddens has called the 'reflexive project of the self' (Giddens, 1991). Considering the 'wealth of the images' coming from the West (Miller, 1992), mass media icons play a role in this project, but their deployments relate to the local worlds. As one student put it, watching global media, 
the Slovene women would get "their "ally" whom they could, for different reasons, identify with'.

In conclusion, considering the disappointments and society's abridgement of young women's 'production of expectation', the image of an independent and professionally accomplished woman, no matter how neurotic or troublesome her post-feminist masquerade of femininity, begins to complicate any notion of the self-evident, transparent correlation between global media idols and their local audiences. It certainly debunks the myth of women's audiences as 'natural collectivity with a constant identity' (Ang and Hermes, 1996: 118). In contrast to their western sisters watching TV re-runs, the primary concern of Slovene college women's audiences is not to strike a pose of a liberated female agency, of a 'coming age of a different law', to use Foucault's (1990: 7) words. In light of conservative attempts to pull women back into family and domesticity, theirs may rather be to secure it. How and why this position departs from the critical feminist reading of Ally in this respect is not a superficial question, but a critical one - both pedagogically and theoretically.

\section{Global culture and local meanings}

Post-feminism as a term has acquired a wide range of meanings which are often mutually exclusive and contradictory in respect to whether they are deployed in theoretical, political or media discourses (Gough-Yates, 2003; Jones, 2003; Lotz, 2001; van Zoonen, 1994). Whereas some have used the term 'post-feminism' to delineate a new theoretical terrain of possibilities to contest the modernist, patriarchal and imperialist frameworks still operating behind western feminist epistemology, others have seen it more in terms of a reactionary body of political discourses and cultural, massmediated practices of recasting women in a traditionalist, family-oriented fashion, depoliticizing feminist struggles. The two narratives reconstructed in this article suggest that post-feminism should be used less as a taxonomic category of ordering political and ideological realms concentrated around popular and official definitions of the woman in the West, but more as a global meeting point of cultural discourse and popular forms of women's self-reflexivity. In the West, post-feminism may constitute a potent ideological vehicle while its visual rhetoric in mass media allows the new generation of women to insert their separate identity and disassociate themselves from their mothers' political dreams (Jones, 2003: 318). In the post-socialist cultures, post-feminism may be seen as granting, in its female form of consumption, a compensation for state-controlled bars to commodity culture and female pleasure in socialism (Einhorn, 1993). For a younger generation, it offers a way of inserting a generational divide as well as projecting a future. In its combined, global effect, postfeminism at once proposes new hegemonic ways of looking at women and 
provides grounds for women's audiences worldwide to challenge, through proposed Western imagery, their own local gendered histories.

The challenge in Slovenia relates to the social experience of the "transition' and restructuring of gender relations. For young viewers, especially women in Slovenia, Ally McBeal is but one of many global cultural sites on which to imagine their own world, to come to terms with their own social histories. These histories are enmeshed in narratives of the past as well as social fantasies of the future. Erika Harris (2002: 192) writes that the pressures of globalization contribute to 'fragmentation of cultures': 'These cultures are a result of memories, local ways of thinking, customs and norms that grew out of the necessities of local struggles, or out of reinterpreted histories and retold stories.' Many of the local struggles, entangled in new global mass-mediated fantasies, concern expectations about the effects that the shift to the market economy and democracy will have on social relations and structures of gender. This 'production of expectation' is entwined within contradictory notions of social history and progress. With respect to the former, paradoxically, it is precisely the projection of patriarchal imagery of the domesticated female - the very one that socialist discourse and politics tried to dismiss as the ideological property of the capitalist system - which for the young viewers symbolizes the remnants of the socialist social history of gender. Regarding the latter, in contrast to their mothers who lived under the spell of socialist ideology, which told them that once women had entered the production force their liberation was achieved, the transition generation perceives socialism as a regime that oppressed women. For them, real liberation comes from the West. Avoiding the legacy of the 'token woman', however, they also 'try to avoid "feminist conflicts" and try to build their public promotion above all as good professionals and experts' (Jalušić, 1999: 125). This is in fact a meeting point between feminism and socialism. By a strange stroke of fate, western feminism and socialism come to play a shared role of the Other.

Engaging in the fictional life of Ally $M c B e a l$ provides different fantasy materials for different audiences. As any fantasy contains omissions, this one lacks historical facts concerning past and present women's struggles both in the West and the former socialist states. This gives us no reason to dismiss popular receptions of global culture. As Slavoj Zižek writes:

Few things are worthy of more contempt, few views are more ideological . . . than those of the Western academic leftist with a job who arrogantly dismisses (or, worse, paternalistically 'understands') the Eastern European from a communist state who yearns for Western liberal democracy and some commodities. (2003: 10)

Read from the perspective of young Slovene female audiences con252 suming the image of Ally McBeal, this view provides solid ground for 
historical sensitivity when engaging in political debates about the promises and pitfalls of global culture. But this should not prevent us from engaging ourselves in critical readings of global cultural texts. As I was completing this article, national TVS was showing the seventh episode of The Mary Tyler Moore Show. Not only is contemporary television becoming globally available, but also television history. Thus, studying global genres may provide a good starting point for both cultural criticism and classroom pedagogy to begin to intercept global popular fantasies with cultural memory.

\section{Acknowledgements}

I wish to thank Gordana Crnković for her encouragement to complete this article. I also express my gratitude to anonymous reviewers, and especially Joke Hermes for constructive criticism and useful comments.

\section{References}

Andall, J. (2003) 'Introduction: The Space Between - Gender Politics and Immigration Politics in Europe', in J. Andall (ed.) Gender and Ethnicity in Contemporary Europe, pp. 1-20. Oxford: Berg.

Ang, I. (1991) Desperately Seeking the Audience. London: Routledge.

Ang, I. (ed.) (1996) Living Room Wars. Rethinking Media Audiences for a Postmodern World. London: Routledge.

Ang, I. and J. Hermes (1996) 'Gender and/in Media Consumption', in I. Ang (ed.) Living Room Wars. Rethinking Media Audiences for a Postmodern World, pp. 109-29. London: Routledge.

Appelo, T. (1999) Ally McBeal: The Official Mini Guide. Los Angeles, CA:

Twentieth Century Fox Home Entertainment.

Cooper, B. (2001) 'Unapologetic Women, "Comic Men" and Feminine Spectatorship in David E. Kelly's Ally McBeal', Critical Studies in Mass Communication 18(4): 416-35.

Crnković, G.P. (2003) “"Have a Nice Day": From the Balkan War to the American Dream and the Things that Shape the Way We See Each Other', in S.P. Ramet and G.P. Crnković (eds) Kazaaam! Splat! Ploof! The American Impact on European Popular Culture Since 1945, pp. 158-72. Lanham, MD: Rowman and Littlefield.

Curti, L. (1992) 'What Is Real and What Is Not: Female Fabulations in Cultural Analysis', in L. Grossberg, C. Nelson and P. Treichler (eds) Cultural Studies, pp. 134-53. New York: Routledge.

Doane, M.A. (1987) 'The Moving Image: Pathos and the Maternal', in The Desire to Desire: Women's Film of the 1940s, pp. 70-95. Bloomington: Indiana University Press.

Dow, B.J. (2002) 'Ally McBeal, Lifestyle Feminism, and the Politics of Personal Happiness', Communication Review 5: 259-64. 
Dubrofsky, R. (2002) 'Ally McBeal as Post-feminist Icon: The Aestheticizing and Fetishizing of the Independent Working Woman', Communication Review 5: $265-84$.

Einhorn, B. (1993) Cinderella Goes to Market. Citizenship, Gender and Women's Movements in East Central Europe. London: Verso.

Foucault, M. (1990) The History of Sexuality, Vol. 1. New York: Vintage.

Giddens, A. (1991) Modernity and Self-identity. Self and Society in the Late Modern Age. Stanford, CA: Stanford University Press.

Gough-Yates, A. (2003) Understanding Women's Magazines. Publishing, Markets and Readerships. London: Routledge.

Harris, E. (2002) Nationalism and Democratisation. Politics of Slovakia and Slovenia. Burlington: Ashgate.

Hermes, J. (1995) Reading Women's Magazines. Cambridge: Polity Press.

Jalušić, V. (1999) 'Women in Post-socialist Slovenia: Socially Adapted, Politically Marginalized', in S.P. Ramet (ed.) Gender Politics in the Western Balkans, pp. 109-29. University Park: Pennsylvania State University Press. Jogan, M. (2000) 'Postsocializem in androcentrizem', Družboslovne razprave 16(34-5): 9-30.

Jones, A. (ed.) (2003) 'Feminism, Incorporated: Reading "Post-feminism" in an Anti-feminist Age', in The Feminism and Visual Culture Reader, pp. 314-29. London: Routledge.

Kim, L.S. (2001) "'Sex and the Single Girl” in Postfeminism', Television and New Media 2(4): 319-34.

Knapp, S. (1989) 'Collective Memory and the Actual Past', Representations 26 : 123-49.

Lotz, A. (2001) 'Postfeminist Television Criticism: Rehabilitating Critical Terms and Identifying Postfeminist Attributes', Feminist Media Studies 1(1): 105-21.

Lupša, M. (2001) 'A Country of Women?', Jana (16 Oct.): 3.

Marek, J.G. (1999) 'The Practice and Ally McBeal: A New Image for Women Lawyers on Television?', Journal of American Culture 22(1) (electronic version, Academic Search Premier).

Margolis, H. (2000) 'This Is Not a Show about Lawyers', Australian Screen Education 20-1 (electronic version, Academic Search Premier).

Mellencamp, P. (1986) 'Situation Comedy, Feminism and Freud. Discourses of Gracie and Lucy', in T. Modleski (ed.) Studies in Entertainment, pp. 80-95. Bloomington: Indiana University Press.

Miller, D. (1992) 'The Young and the Restless in Trinidad: A Case of the Local and the Global in Mass Consumption', in R. Silverstone and E. Hirsch (eds) Consuming Technologies: Media and Information in Domestic Spaces, pp. 163-82. London: Routledge.

Moseley, R. and J. Read (2002) "Having it Ally": Popular Television (Post)Feminism', Feminist Media Studies 2(2): 231-49.

Nochimson, M. (2000) 'Ally McBeal: Brightness Falls from the Air', Film 254 Quarterly 53(3): 25-32. 
Radway, J.A. (1986) Reading the Romance. Women, Patriarchy and Popular

Literature. Chapel Hill: University of North Carolina Press.

Ramet, S.P. (ed.) (1999) 'Introduction', in Gender Politics in the Western

Balkans, pp. 3-10. University Park: Pennsylvania State University Press.

Rener, T. (2000) 'Adolescentke' ['Adolescents'], Družboslovne razprave 16(34-5): 207-17.

Spigel, L. (1995) 'From the Dark Ages to the Golden Age: Women's Memories and Television Reruns', Screen 36(1): 16-33.

Taylor, E. (1989) Prime Time Families. Berkeley: University of California Press. Tueth, S.J.M. (2000) 'TV's Urban Situation Comedies of the 1990s', Journal of Popular Film and Television 28(3): 99-107.

Ule, M., T. Rener, M. Mencin Čeplak and B. Tivadar (2000) The Social

Vulnerability of the Young. Maribor, Ljubljana: Aristej/Office for Youth.

Van Zoonen, L. (1994) Feminist Media Studies. London: Sage.

Vidmar, K.H. (1995) 'The Importance of Being Mad: The 1950s Comic

Imagination and Discourses on Youth', paper presented at the Sixth Annual Berkeley Symposium, 11-12 March, Berkeley, California.

Vidmar, K.H. (2002) 'Naša žena and the Image of Mother: Contradictions and Oppositions, 1991-2000', in M. Hrženjak (ed.) Making Her Up: Women's

Magazines in Slovenia, pp. 34-55. Ljubljana: Peace Institute.

Vidmar, K.H. and M. Antic (forthcoming) The Construction of Woman's Identity in Socialism: The Case of Slovenia.

Žižek, S. (2003) 'Kje je prava nevarnost' ['Where Is the Real Danger?'], Delo 22(3): 10-12.

\section{Biographical note}

Ksenija Vidmar-Horvat obtained her PhD from University of California, Davis. At present, she is an assistant professor at the Department of Sociology, Faculty of Arts, University of Ljubljana, Slovenia, where she teaches on cultural theory, global media and gender. She has edited a volume on women's genres. Her most recent works, 'Naša žena and the Image of Mother: Contradictions and Oppositions, 1991-2000' (Peace Institute, 2002) and The Construction of Woman's Identity in Socialism: The Case of Slovenia (with M. Antic, forthcoming) focus on cultural representations of women in socialist and post-socialist Slovenia. ADDREss: Department of Sociology, Faculty of Arts, University of Ljubljana, Askerceva 2, 1000 Ljubljana, Slovenia. [email: ksenija.vidmar@ff.uni-lj.si] 